\title{
An Evaluation of Wood Pulp Paper Durability
}

E. L. Graminski and E. E. Toth

Stability and Standards Section

Polymers Division

February 15, 1977

Progress Report Covering the Period

October 1, 1976 to September 30, 1977

Prepared for

Bureau of Engraving and Printing U.S. Department of the Treasury

Washington, D.C. 20401 



\section{AN EVALUATION OF WOOD PULP PAPER DURABILITY}

E. L. Graminski and E. E. Toth

Stability and Standards Section

Polymers Division

February 15, 1977

Porgress Report Covering the Period

October 1, 1976 to September 30, 1977

NOTE: This document has been prepared for the use of the Bureau of Engraving and Printing. Responsibility for its further use rests with that agency.

Prepared for

Bureau of Engraving and Printing

U.S. Department of the Treasury

Washington, D.C. 20401

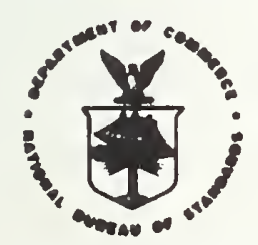

U.S. DEPARTMENT OF COMMERCE, Juanita M. Kreps, Secretary

Dr. Sidnoy Haman. Undor Secrotary

Jordan J. Beruch. Assistent Secrotary for Sclonce and Technology

NATIONAL BUREAU OF STANDARDS. Emest Ambler, Director 

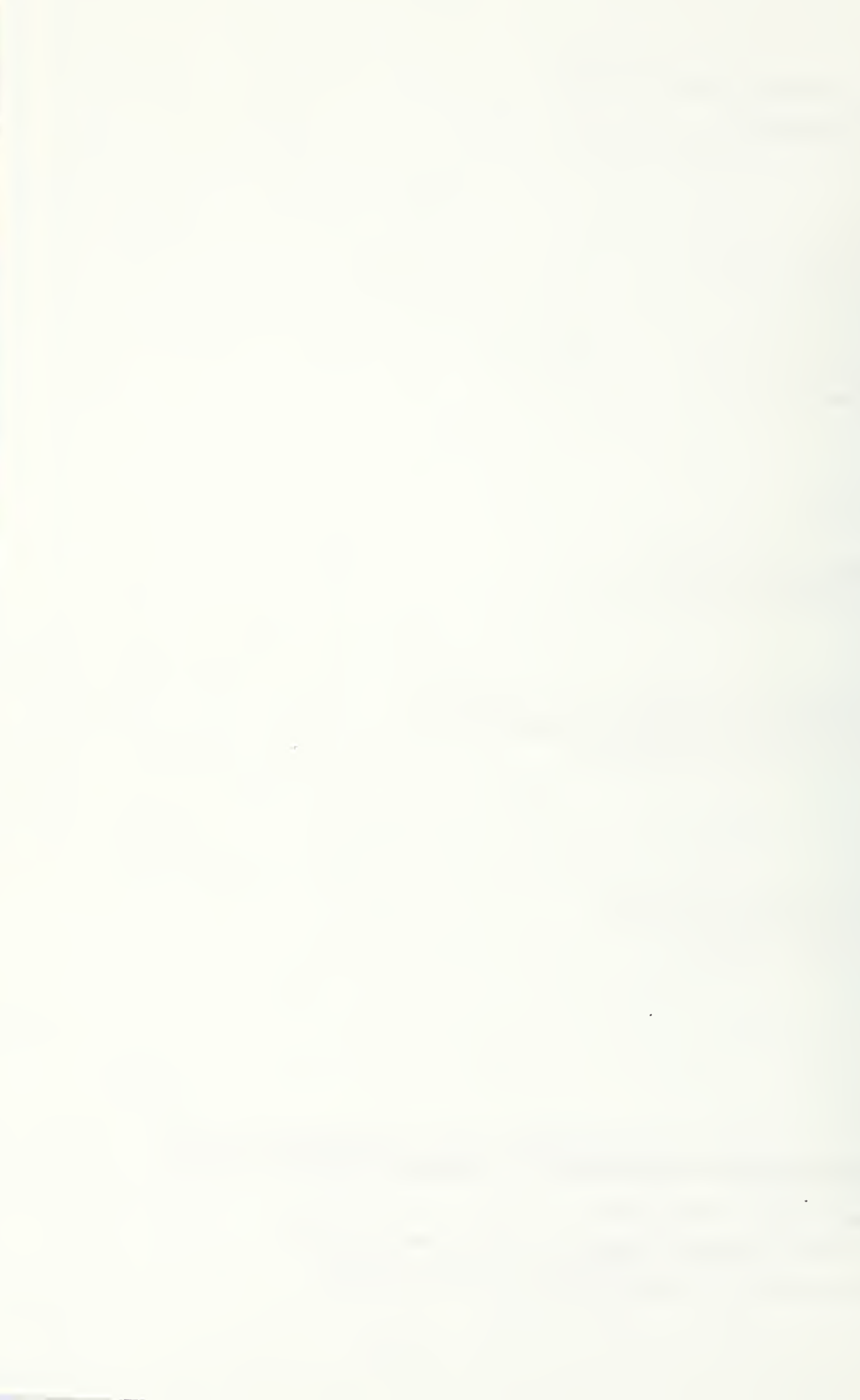
Page

1. Summary . . . . . . . . . . . . . . . . . 11

2. Irtrociuction . . . . . . . . . . . . . . . . 3

3. Experimental Details . . . . . . . . . . . . . . . 4

3.1 Beating . . . . . . . . . . . . . . . . 4

3.2 Density • • • • • • . . . • . . . • . . . 4

3.3 Durability . • . . . . . . . . . . . . . 4

3.4 Fiber Length Distribution . . . . . . . . . . . 4

3.5 Handsheet Preparation . . . . . . . . . . . 5

3. 6 Modification of Paper with Acrylic Resins . . . . 5

3. 7 Wet Strength Resin Treatment . . . . . . . . . . 6

4. Fiber Iength Distribution of Wood Pulp . . . . . . . . 7

4.1 Background . . . . . . . . . . . . . . 7

4.2 Experimental • . • . . . . . . . . . . . 7

4. 3 Results and Discussion . . . . . . . . . . . . 8

5. The Physical Properties of Handsheets Made From

Classified Wood Pulp . . . . . . . . . . . . . . 9

5.1 Backgrounā • . . . . . . . . . . . . . . . . . 9

5.2 Experimental . . . . . . . . . . . . . . . 9

5.3 Results and Discussion . . . . . . . . . . . . 10

6. The Effect of Pulp Blending on the Durability of

Wood Pulp Papers . . . . . . . . . . . . . 12

6.1 Background . . . . . . . . . . . . . . . . 12

6.2 Experimental . . . . . . . . . . . . . . . . 12

6.3 Results and Discussion . . . . . . . . . . . . 12 


\section{Page}

7. Modification of Wood Pulp Papers with Acrylic Latexes . . • • • • . • . . . . . . . . . . 14 7.1 Background... . . . . . . . . . . 14 7.2 Experimental . . . . . . . . . . . 15 7.3 Results and Discussion . . . . . . . . . 15 8. Bioliography . . . . . . . . . . . . . . 17 
Currency has been printed customarily on high grade rag paper owing to its superior durability. During the past several years the cost of raw material for rag pulps has risen tremendously and the thought of using high quality wood pulp papers as a means of lowering the cost of currency manufacture has been advanced. However, it would not be cost effective to use a wood pulp paper unless its aurability was only slightly lower than regular rag currency paper. Otherwise the cost of replacing worn out currency would soon exceed the savings realized by using a less expensive paper.

During the past several years extensive work had been done on rag currency paper to resolve the origin of its superior durability. In addition, many chemical modifications of currency paper were evaluated as means for further increasing the durability of the paper. It was decided to develop similar fundamental information on wood pulp paper and to evaluate the chemical modifications which appeared promising for rag currency paper.

An estimate of fiber length distribution of untreated and mechanically treated wood pulps was determined. Wood pulp was fractionated by fiber length and handsheets were made from the various fractions. The mechanical and pinysical properties of these handsheets were determined. The possibility of further reducing the cost of durable wood pulp papers was investigated by using less expensive haräwood pulp, mechanically treated separately, then blended with softwood pulps to incorporate certain structural elements believea to be essential for good durability. Finally wood pulp handsheets were treated with acrylic resins by the beater addition and saturation techniques and the uurability of the modifieu paper was evaluated.

Fiver length distribution was assessed by the classification tecinique according to Tappi method T233-os-75. Handsheets were prepared from the various fractions by the standard procedure. Standara Tappi methods were used to äetermine the physical properties of the papers. Durability of the papers was estimated with the aid of the NBS paper flexing apparatus. The extent of decline in physical properties as a function of flexing was used as a measure of durability. Modification of handsheets with acrylic resins was done by beater aduition prior to sheet formation while modification by saturation technique was done with the aid of a laboratory size press. 
Considerably more long fiber was contained in wood pulp stock than in rag currency paper stock. The differences in physical and mechanical properties of handsheets made from the various fiber length fractions of wood pulp were small in comparison to that observed in handsheets made from fractionatea rag currency stock. Apparently large differences in fiber morphology exist between the various rag currency paper fractions but not between the wood pulp fractions.

The aurability of wood pulp hanasheets was affected by the addition of hardwood pulps to softwood pulps. Hardwood pulp naa to be mechanically treated extensively in order for hanasineets to have an acceptable level of ciurability. The results of this study indicated that it might be possible to produce an even less expensive wood pulp paper suitable for currency by a judicious choice of hardwood and softwood pulps. A critical factor is the mechanical treatment rendered to each pulp prior to blending.

Apparently many of the commonly accepted notions, such as the necessity for a large amount of long fibers for durable papers, are without foundation. The real factors contributing to high durability have not yet been adequately identified. The present rag currency paper should be investigated thoroughly in order to identify the factors which contribute prominently to the durability of paper. The importance of fiber morphology in paper durability must be established in the immediate future. success in making a wood pulp paper having an optimum duravility largely depends on identifying the factors important for durable papers. 


\section{INTRODUCTION}

The durability of paper made from rag pulps is generally greater than that of paper made from wood pulps. The durability of rag papers is not immediately assured since the fiber source and mechanical processing of the pulps in advance of paper making are critical variables. Nevertheless, it is generally felt that greater durability can be developed with cotton and linen pulps than with wood pulps. The expense of rag papers relative to wood pulp papers cannot be ignored, however, and there is always the notion that for some applications it might be more cost effective to use a less expensive wood pulp paper having only a modicum of lower durability than a high quality rag paper.

The provability of making high durability wood papers woulu ve greatly enhanced by a knowledge of the reasons for the high durability of rag papers. It is generally assumed that the main reasons for rag paper durability are the mechanical properties of the fibers and the morphological changes which the fibers undergo during the mechanical treatment prior to paper making. There are no good data for the mechanical properties of single fibers of cotton and linen in the literature (1). Some information on fiber length distribution of currency stock was developed (2) but there is essentially no information on the slenderness, curl and coarseness of currency paper fibers.

Although currency paper is quite durable there has been a desire to enhance its durability further. During the past several years extensive work was done determining the factors important to currency paper durability and on modifying the paper to improve its aurability. The effect of beating and wet pressing, fiber length distribution and the adaition of synthetic latexes to rag paper were investigatea. Since a similar investigation was not done on wood pulp paper it was decided to conduct these experiments on hanasheets made from wood pulp and to compare the results with those obtained with rag papers. 
3. EXPERIMENTAL DETAILS

\subsection{Beating}

Beating was done similarly to that specified in the Canadian Pulp and Paper Association Test Method C7 except that $40 \mathrm{~g}$ of pulp was soaked in $360 \mathrm{~cm}^{3}$ of water for at least one hour prior to beating. The wet pulp was distributed evenly over the bedplate prior to beating. There was no clearance between bedplate and roll. The beating was done at $33.3 \mathrm{~N}(3.4 \mathrm{kgf})$ and a relative velocity of roll to bedplate of $6 \mathrm{~m} / \mathrm{sec}$ for either 5,10 , or 20 thousand revolutions.

\subsection{Density}

Handsheets were cut to $10 \times 10 \mathrm{~cm}$ and the thickness of each sheet was aetermined at 10 different locations according to TAPPI Method T4lios-76. The average of the 10 thickness measurements was considered to be the sheet thickness. From the measurement of length, width and thickness the volume in $\mathrm{cm}^{3}$ was calculated. The weight of each sheet, previously conditioned according to TAPPI Standard T4020s-70, was measurea to the nearest milligram on an analytical balance. The density was calculated by dividing the weight by the volume of the sireet.

\subsection{Durability}

Specimens $15 \times 30 \mathrm{~cm}$ were flexed 1000 times over $3.18 \mathrm{~mm}$ rollers while constrained by a $700 \mathrm{~g}$ free hanging weight on the NBS paper flexer. Only that portion which passed over both rollers was used for subsequent testing. The air permeability of each specimen was àetermined at six different locations with a commercial tester prior to cutting into small testspecimens as described in a previous NBS report (9). The extent of decline in physical properties as a consequence of flexing was consiäered to be a measure of paper durability.

\subsection{Fiber Length Distribution}

The fiber length of pulp was determined according to TAPPI Method T233-0s-75. 


\section{5 Handsheet Preparation}

Aliquots of beaten pulp sufficient to make a $30 \times 30 \mathrm{~cm}$ handsheet of aesired $\mathrm{g} / \mathrm{m}^{2}$ were diluted with approximately one $\mathrm{dm}^{3}$ of water and disintegrated for 7,500 revolutions in a commercial disintegrator. The suspension was added to the deckle box of the handsheet machine and a sheet was formed. The wire containing the formed sheet was placed on a blotter, covered with a felt, and consolidated by pressing the sheet with a $30 \mathrm{~cm}$ long roller weighing $22.5 \mathrm{~kg}$. The sheet was removed from the wire, placed between felts, and passed through the roll press of the handsheet machine at the maximum pressure possible. After pressing, the sheet was placed on a drum drier at $95^{\circ} \mathrm{C}$ for approximately four minutes.

\subsection{Modification of Paper with Acrylic Resins}

There are two methods for modifying paper with polymer latexes. One is the so-called beater addition method which actually does not take place in a beater but in a mixing chest where the beaten pulp can be agitated gently in the presence of a latex. The second method is called paper saturation which involves saturating dry paper with a latex, squeezing out the excess, followed by drying.

\section{A. Beater Addition Technique}

An aliquot of the beaten pulp, sufficient to make a $30 \times 30 \mathrm{~cm}$ handsheet of $70 \mathrm{~g} / \mathrm{m}^{2}$, was diluted with $600 \mathrm{~cm}$ distilled water and disintegrated for 7,500 revolutions in a British disintegrator. The $\mathrm{pH}$ was adjusted to 9 using IN NaOH. A cationic retention aid was added to the slurry in the amount of four percent based on latex solids to be deposited on the fibers. The retention aid was added from a sufficient quantity of a one percent solution diluted with $30 \mathrm{~cm}^{3}$ distilled water. Only two thirds of the retention aid was added at the start. The mixture of pulp suspension and retention aid was stirred five minutes prior to latex addition to allow the retention aid to be exhausted from solution. The $\mathrm{pH}$ of the mixture was then decreased to 4.0 with $0.5 \mathrm{~N} \mathrm{H}_{2} \mathrm{SO}_{4}$. 

4. FIBER LENGTH DISTRIBUTION OF WOOD PULPS

4.1 Background

The average fiber length is greater for unbeaten rag pulps than for unbeaten wood pulps. However, pulp fibers are not suitable for paper manufacture as produced and it is necessary to subject the fibers to mechanical action before good paper can be made. During the beating or refining process the fibers imbibe water and swell, fibrils form and extend from the fiber wall, fibers are cut, surface area increases, the outer walls of the fiber are removed and internal bonds are broken. The morphological characteristics of pulp fibers are changed considerably, and it is these morphological changes which affect the fiber network structure of paper. One of the most apparent changes which occurs during the mechanical treatment of rag pulps is a change in the fiber length distribution.

In a previous study on fiber length distribution (2), it was shown that currency paper stock contained a surprisingly small amount of long fibers. Only 16 percent of the total furnish consisted of fibers with a length approximately $1.17 \mathrm{~mm}$ or longer. Perhaps the most surprising fact was that 32 percent of the furnish consisted of fibers $0.2 \mathrm{~mm}$ or shorter. Currency paper consists of a high percentage of short fibers and yet is has excellent durability.

Several wood pulps were fractionated in order to obtain an estimate of their fiber length distribution relative to currency paper stock. Three softwood and one hardwood bleached kraft pulps were chosen. In addition, the effect of the beating on fiber length distribution was determined for one of the softwood pulps.

\subsection{Experimental}

The procedure for determining fiber length of pulp by classification is described in section 3 of this report.

The pulps used in this investigation were as follows:

(a) Pulp "F" bleached softwood kraft consisting of $95 \%$ spruce and hemlock anci 58 pine. 
(b) Northern Softwood. Bleached softwood kraft consisting of $80 \%$ spruce and/or hemlock, $15 \%$ balsam fir and 5\% douglas fir.

(c) Southern Softwood. Bleached softwood kraft containing $90 \%$ short leaf pine and $10 \%$ scotch pine.

(d) Hardwood. Bleached hardwood kraft containing 97\% alcier, poplar, maple, populus, birch, oak and/or chestnut and sweetgum and 38 short leaf pine.

\subsection{Results and Discussion}

All three softwood pulps beaten or unbeaten contained considerably more long fiber than currency beater stock while the naroiwood pulp has consiaerably less long fibers ( $\mathrm{Table} 1$ ). It has been generally believed that a large portion of long fibers is essential for strong durable papers. It is apparent from the results of this study that factors in addition to fiber length are important for durable papers.

During beating, fibers are cut resulting in a shortening of long fibers anci an increase in debris. Laboratory mechanical treatment is significantly different from that employed by industry and the results obtained in this study are not necessarily indicative of morphological changes which occur during commerical paper manufacturing. Nevertheless, the morphological changes in rag pulp fibers during mechanical treatment is considerably different from wood pulps regardless of the mechanical treatment equipment used. It is quite apparent from this stuay that much could be learned about paper durability by an indepth study of the changes in rag pulp fiber morphology as a function of mechanical refining. 
5. THL PHYSICAL PROPERTIES OF HANDSHEETS MADE FROM CLASSIFIED WOOD PULP

\section{1 backgrounci}

The various fiber length fractions wlit ch compose paper pulps affect distinct physical properties of paper in different ways. The long fibered fraction has a great effect on the tear strength and folding endurance of paper. The very short fiber fraction has a great effect on the density of paper winich in turn affects the moaulus and bending stiffness. But regaraless of the importance of an individual fiber fraction on a aistinct paper property each of the otiner fractions also has some influence on the property in question.

One mears of ciemonstrating the importance of the various fiber fractions on physical properties is to make handsheets from each of the individual fractions and to determine the physical properties of these sheets. Such a study was done previously on currency paper stock (2). The results of that stuay indicated that each fiber fraction was characteristically aifferent from each of the other fractions. The mechanical properties of handsheets made from the various fractions differeu consiaerably. The handsheets made from the unfractionateu pulp were superior in all respects and demonstrated the synergistic interaction between the various fiber fractions in whole pulp. It remained to be seen whether wood pulp possessed similar characteristics.

For this investigation pulp "F" was used since extensive work witn tnis pulp snowed it had excellent mechanical properties. 'Ine puip was beaten to various degrees in a laboratory mill, fractionated, and sheets were prepared from the various fractions.

\subsection{Experimental}

The methods used for the classification of pulp by fiber length, pulp beating, handsheet preparation, measurement of paper density and assessment of paper durability are given in section 3 of this report. A total of $240 \mathrm{~g}$ of type $\mathrm{F}$ beaten pulp was fractionated in $40 \mathrm{~g}$ batches for each set of beater conaitions. The various fractions collected on each screen were combined, diluted to one-half percent consistency with water and blended thoroughly and then dewatered by filtration. 
namasheets were made only from the first and second fractions as there were insufficient quantities of fractions three and four to make a sufficient number of handsheets for testing. In addition, sheets were made from 95 percent of iraction one and approximately five percent of fraction three.

\subsection{Results ana Discussion}

Significant differences were observed between rag (2) and wood pulp handsheets prepared from fractionated pulp ( $\mathrm{Tab}$ les 2-5). Handsheets prepared from fractionated currency stock exhibited larger differences in physical properties between the various fractions while the differences observed with the wood pulp handsheets were relatively small. One of the major aifferences between the rag and wood pulp handsheets was the variation in sheet density as a function of fiber fraction. sheet density increased with decreasing fiber length to a much greater extent with currency stock than with wood pulp as shown in Fig. 1. Apparently the differences in fiber morphology between the various fractions are much greater in currency stock than in wood pulp stock. In fact the small differences in sheet density observed between the various wood pulp fractions might easily result from the difference in fiber length distributions. As the fiber length decreases the fivers can form a more compact fiber network.

The aata suggest that the greatest morphological change wnich occure during the beating of wooc pulp in a laboratory beater is fiber shortening. Apparently the morphological cnanges occurring during the beating of cotton are more numerous and consicierably different from those occurring with wood pulp fibers. It is reasonable to assume that the changes in fiber morphology occurring during the beating of rag pulps contribute greatly to the superior durability of rag papers. An indeptin study of the morphological changes in pulp fibers during beating of rag pulps for currency paper would be invaluable. The study would assist in explaining the reasons for the superior durability of rag paper and be extremely helpful in designing a durable wood pulp paper for currency.

The retention of benaing stiffness after flexing variea from a low of 26 percent for the 14 mesh fraction beaten for 5000 revolutions in the laboratory mill to 57 percent for the unclassifiec pulp beaten for 20,000 revolutions. While the difference in stiffness retention was great, there was only a 
29 percent difference between the final stiffness of these two papers. Although good stiffness retention is a desirable feature for currency paper it is not the only criterion for benciing stiffness to be consiciered. Currency is redeemed wiren its stiffness falls below a certain value $(3,4)$. Although the stiffness retention for a paper could be high, the paper mignt be considered unsuitable for currency if the bending stiffness of the unflexed paper was near the stiffness level of redeemed currency. In such an instance only a moderate amount of handling would result in a sufficient decline of bending stiffness to render currency unfit for recirculation. The net result would be a decrease in the circulation life of currency even though the paper would have a high retention of stiffness.

Little if any change in physical properties occurred as the result of adding five percent of the 65 mesh fraction to the 14 mesh fraction. Apparently the quantity of 65 mesh fraction used in this investigation was too small to have any significant effect on the physical properties of paper. This is somewhat surprising since this is precisely the amount of 65 mesh fraction normally found in this pulp (see Table 1). Aaciitional work will be necessary before any conclusions can be made on the effect of specific pulp fractions on the mechanical properties of paper. 


\section{THE EFFECT OF PULP BLENDING ON THE DURABILITY OF WOOD PULP PAPERS}

\section{1 background}

I'ne debris in currency furnish, which appears to be an inportant component in currency paper, is produced during the mechanical refining of the pulp. The production of the debris or fines involves a considerable consumption of energy, often results in considerable shortening of fiber length and results in extensive water imbibition by the fibers. Consequently, water removal by pressing and evaporation is escessive. It would be advantageous to use a less expensive short fibered pulp such as a hardwood pulp for the production of fines. These fines could then be blended with a more expensive softwood long fiber pulp mechanically treated separately to produce a durable paper at lower cost and with lower energy consumption. This investigation was designed to assess the feasibility of this hypothesis.

\subsection{Experimental}

The conditions for beating, handsheet formation and estimating paper durability were described in section 3 of this report.

\subsection{Results and Discussion}

As tne proportion of harowood pulp, beaten for 10,000 revolutions in the laboratory mill increased, the mechanical properties of the handsheets decreased for both softwood pulps. nardwood pulp fibers are coarse and rigid and unless subjected to sufficient mechanical treatment in preparation for paper making will form porous, low density, weak paper. The fact that the density of the handsheets declined somewhat with increasing quantities of hardwood indicated insufficient mechanical treatment of the hardwood pulp.

When the hardwood pulp was beaten for 20,000 revolutions and blended with Northern softwood pulp beaten 10,000 revolutions in the laboratory mill the density of the paper increased somewhat with increasing hardwood content (Tables 6-9). In audition the air permeability decreased indicating a more compact fiber network has formea. Small increases in rnechanical properties were observed with the exception of Elmendorf tear, folding endurance and cantilever stiffness. 
The cuecrease in tear and folding endurance was probably the result of decreased fiber length while the decrease in cantilver stiffness was caused in part by the decline in paper thickness.

Retention of stiffness with flexing increased with harawood content when beaten for 20,000 revolutions while little or no effect on stiffness retention was observed when the hardwood was beaten only 10,000 revolutions. These results indicate that it may be possible to manufacture a durable wood pulp paper by blending appropriate softwood and hardwood pulps mechanically treated separately. Additional work would be necessary in order to fully verify the utility of blending softwood and hardwood pulps for durable wood pulp papers.

Although the highest retention of stiffness after flexing occurred witi handsheets containing 70 percent northern softwood and 30 percent hardwood beaten 20,000 revolutions the ultimate stiffness was slightly lower than that of some of the flexed handsheets made from southern softwood and hardwood pulps. However, the thickness of the southern softwood papers was approximately $20 \%$ greater than the Northern softwood-hardwood handsheets. Since the bending moment is related to the cube of the thickness the thicker paper would naturally be stiffer.

The results of this investigation indicate that blending of a wide range of pulps for specific paper properties may be a useful approach in designing a durable wood pulp currency paper. Once again a thorough study of the morphological characteristics of the various pulps would provide valuable information. 


\section{MODIFICATION OF WOOD PULP PAPERS WITH ACRYLIC LATEXES}

\subsection{Background}

Previous investigations on the modification of paper with acrylic latexes resulted in a substantial improvement in stiffness retention. Improvements in stiffness retention occurrea regardless of the modification procedure $(6,7,8,9,10)$. Since the beater addition technique for modifying paper with acrylic resins distributes the resin uniformly throughout the paper and the saturation technique results in a more topical disbursement it appeared deterioration of bending stiffness might occur by at least two separate mechanisms.

The bending stiffness of paper is undoubtedly affected by the stiffness of the fibers and the structure of the fiber network. Conceivably the beater addition technique for modifying paper with acrylic resins enhances stiffness retention of the fibers and in turn the stiffness of paper while the saturation technique enhances stiffness retention brought about by the network structure.

At times the treatment of paper with acrylic resins by beater adcition culminates in structural changes in the fiber network structure which has an adverse effect on stiffness retention (8). Acrylic latexes apparently have an effect on the functionality of the fibrillar component in the fiber network of paper which gives rise to a more porous network. Investigations have shown that this undesirable effect of acrylic resins on paper structure can be reversed by a post-treatrient with a wet strength resin commonly used for wet strength paper. Paper so treated is less porous and does exhibit greater retention of bending stiffness with flexing.

If the bending stiffness of paper does deteriorate by more than one mechanism and ff the modification of paper with acrylic resins by beater addition and saturation affects different mechanism of deterioration it would be reasonable to assume paper modified with acrylic resin by both procedures would result in an optimum improvement in stiffness retention when flexed. Inis investigation was designed to determine whether wood pulp paper treated with acrylic resins by beater adaition and saturation would exhibit superior stiffness retention. 


\subsection{Experimental}

A Northeastern bleached kraft pulp, consisting of $95 \%$ spruce and hemlock and 58 pine, was used in this study. The procedures for beating the pulp, forming the handsheets, modifying the sheets with acrylic resins and estimating the durability of the various papers was described in section 3 of this report.

The regular controls in this investigation consisted of handsheets prepared in the regular manner with untreated beaten fibers. The water controls consisted of the regular controls, subjected to the beater addition procedure but without the addition of any of the additives. Finally the retention aid controls consisted of subjecting the beaten pulp to the peater addition procedure but only adding the retention aid. Durability was estimated according to the procedure described in section 3. Each sheet was cut in half, and one half, selected at random, was flexed.

\subsection{Results anci Discussion}

The double treatment of wood pulp paper with acrylic resins by beater adaition and saturation produces a paper having a stiffness and a high stiffness retention when flexed. Tnis is an excellent property for a currency paper to have. Currency remains in circulation until it is torn, soiled excessively or its stiffness declines below a certain level. A previous study indicated that approximately 94 percent of currency is redeemed because it is limp (11). A more in-depth study inuicated that currency is considered unacceptable for recirculation after its stiffness has declined to a cantilever stiffness in the neighborhood of $93 \mu \mathrm{N} \cdot \mathrm{m}$ or lower (3). An ideal currency would therefore, have a cantilever stiffness substantially in excess of $93 \mu \mathrm{N} \cdot \mathrm{m}$ anci a high retention of stiffriess when flexed. Such currency would be expected to nave a substantially longer circulation life than the present currency.

Modification of paper with acrylic resins by beater addition produces some improvement in stiffness retention but not to the same extent as that producea by saturation. When the beater addition treatment is subsequently followed by treatment with wet strength resin a further improvement in stiffness retention results which is roughly equivalent to 
the improvement produced by saturation alone but the greatest improvement in stiffness retention occurs when the paper is modified with acrylic resins by both beater addition and saturation. There appears to be no advantage in using the wet strength resin post-treatment when the paper is subsequently treated with acrylic resins by saturation.

The double acrylic resin treatment appears to have more advantages than just improving stiffness retention. The strength, elongation to break, energy to break and folaing endurance all exhibit appreciable improvements and are retained to a high degree when flexed. It would seem appropriate to conduct some mill trials with acrylic resin modification of the present currency paper as well as wood pulp papers under consideration for currency paper. Even though laboratory investigations provide useful information on the effect of modifications on paper durability it will be ultimately necessary to manufacture some currency type paper incorporating some of the more promising laboratory modifications. In this way the effect of paper machine variables can be evaluated on the performance of the paper. 


\section{BIBLIOGRAPHY}

1. Fong, J. T., Rehm, R. G. and Graminski, E. L., "A Micro-Degradation Model for Paper," NBSIR 76-1062, April 15, 1976.

2. Graminski, E. L. and Toth, E. E., "Durability of Paper," NBSIR 75-978, December 15, 1975.

3. Storesberry, D. P., Fhilmon, I. and Graminski, E. L., "Evaluation of Methods for Automatically Determining the Fitness of Currency," NBSIR 10-699, February 1, 1972 .

4. Storesberry, D. P., Philmon, I. anci Graminski, E. L., "Evaluation of Methods for Automatically Determining the Fitness of Currency," NBS Report 10-919, September 1, 1972 .

5. Graminski, E. L. in "The Fundamental Properties of Paper Related to Its Uses" (F. Bolam, Ed.) pp. 761-781, Tech. Div. British Paper and Board Industry Fed., London (1976).

6. Graminski, E. L. and Toth, E. E., "Evaluation of Currency and Stamp Papers," NBSIR 73-142, January 30, 1973.

7. Graminski, E. L. and Toth, E. E., "Evaluation of Currency and Stamp Papers," NBSIR 73-274, August 15, 1973.

8. Graminski, E. L. anā Toth, E. E., "Evaluation of Currency and Stamp Papers," NBSIR 74-431, January 2, 1974.

9. Graminski, E. L. and Toth, E. E., "Evaluation of Currency and Stamp Papers," NBSIR 74-571, September 6, 1974.

10. Graminski, E. L. and Toth, E. E., "Evaluation of Currency and Stamp Papers," NBSIR 75-670, February 20, 1975.

11. Graminski, E. L. and Forshee, B. W., "Evaluation of Currency and Stamp Papers, NBS Report 9510, March 31, 1967. 


\section{ACKNOWLEDGEMENT}

The authors wish to thank Mr. Kenneth E. Hermsen and Mr. Virgil F. Seavey for the fiber species analysis of the various pulps used in this investigation. 



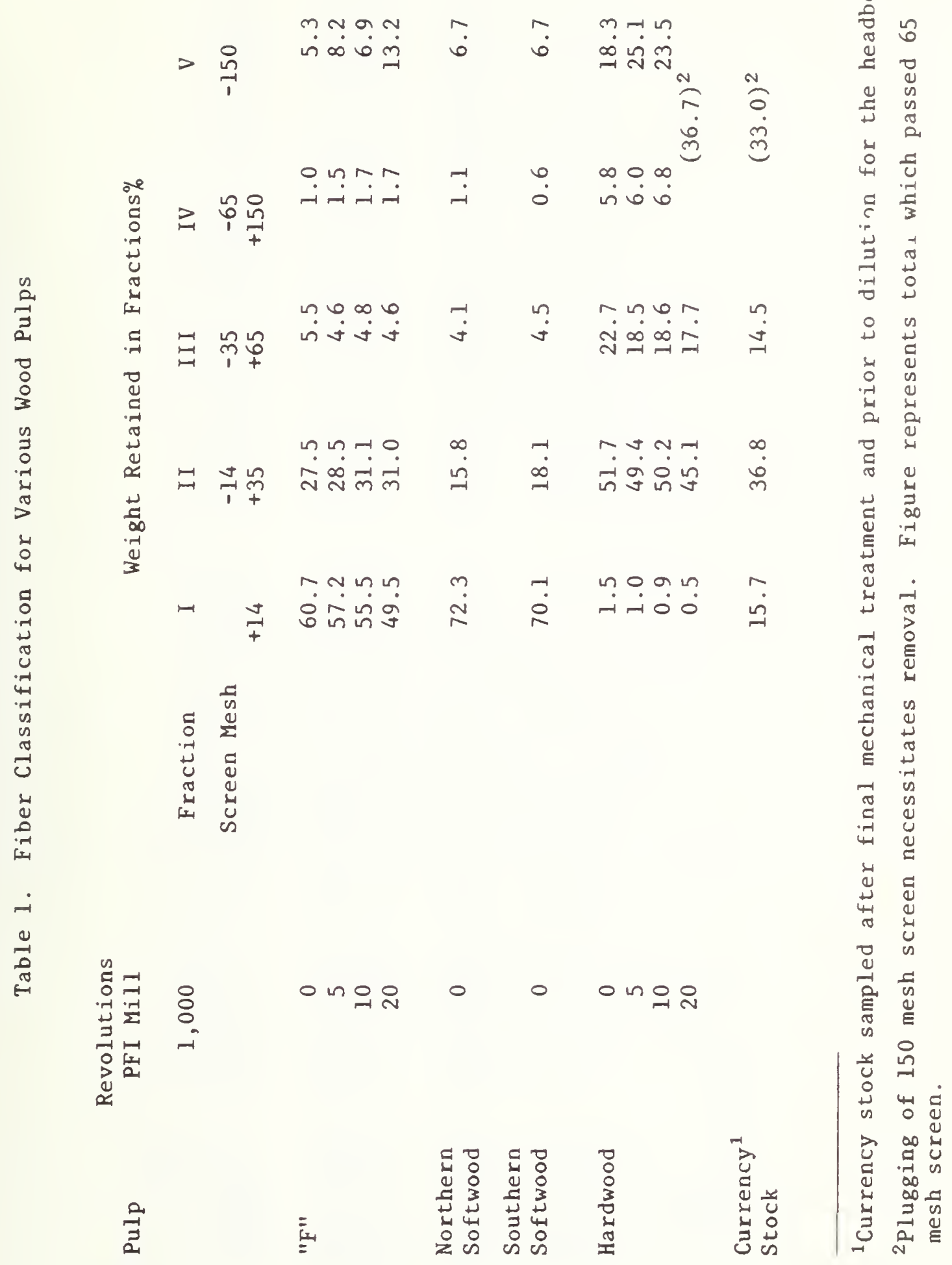




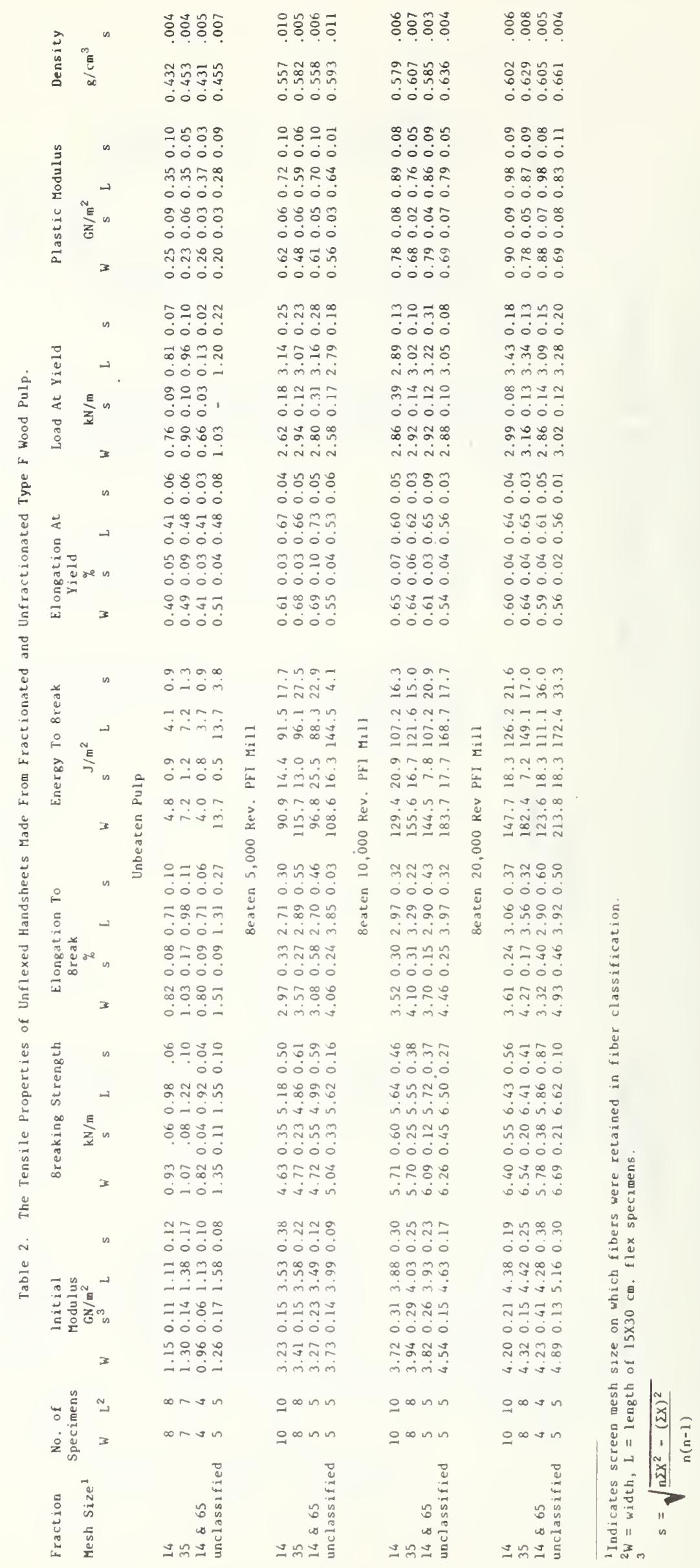




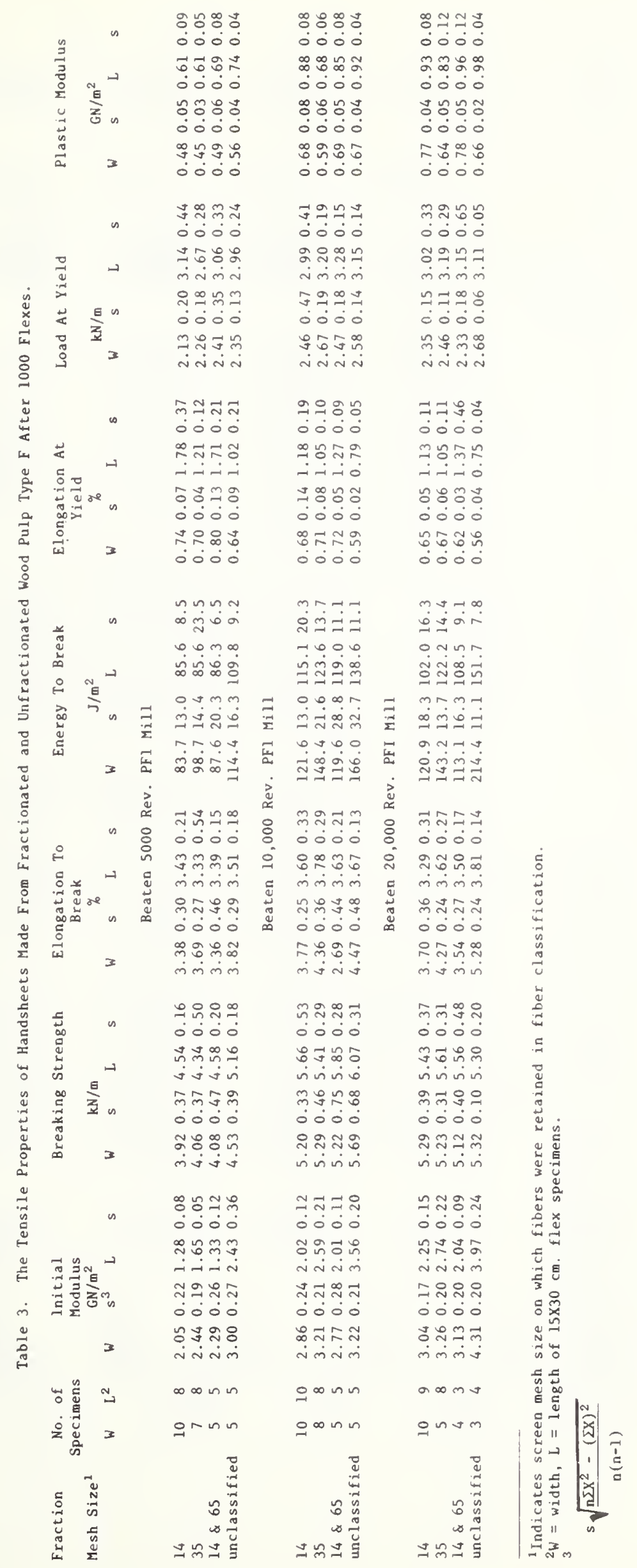




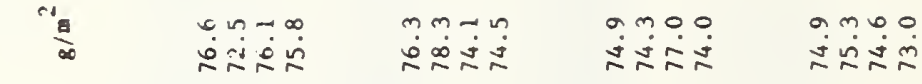

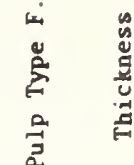

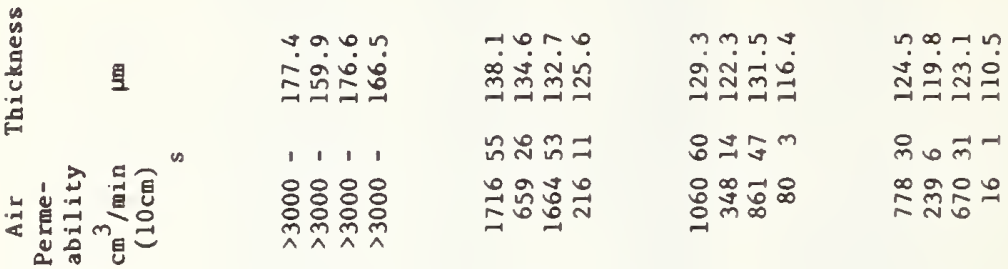

\begin{tabular}{|c|c|c|c|}
\hline n & 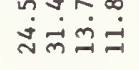 & 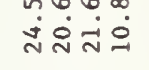 & 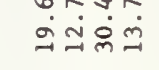 \\
\hline & 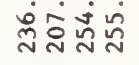 & 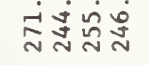 & sid \\
\hline & สโุส సి & 舟 & 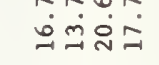 \\
\hline & จู่์ส่ร & 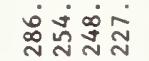 & जีं \\
\hline
\end{tabular}

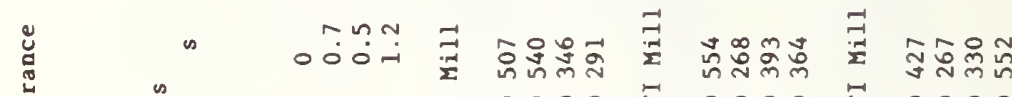

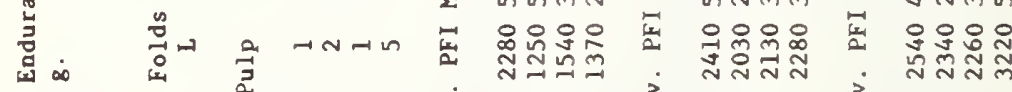

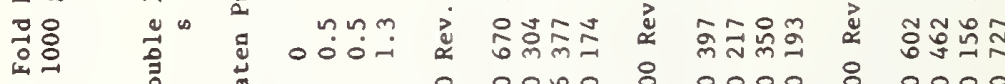

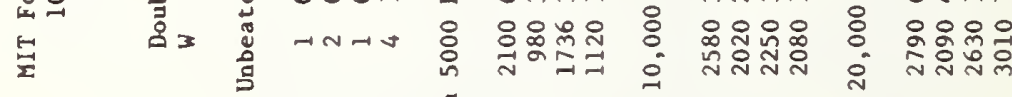

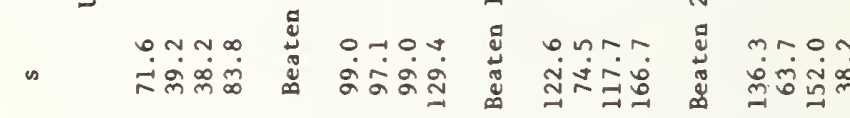

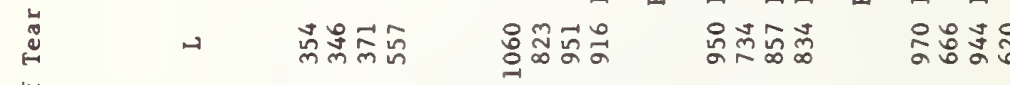

:

刍的它守的

$m \infty \infty$

$0-\infty 0$

$\infty \rightarrow \infty$

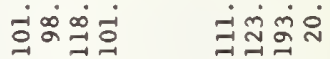

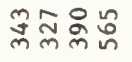

กตกล

ㅎํำํํํำ

๑ํํำสำ

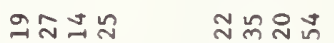

ฌิ

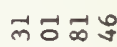

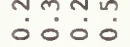

กิำสำ

¿0:0ं

กิกิสิา

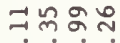

मीं

००ता

สกกน

ㅇํำำำ

긍요융

००००

0000

똥으구

สูกสิก

-i-io

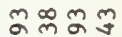

risio

กํํ요

-ion

육구유

:둥

in $\sin$ in

inisio

तi

岁离

$O_{\infty} \infty \min$

O $\infty$ in $n$

O

$\infty n+n$

$\stackrel{0}{\circ} \infty n$

$0 \infty$ n $n$

인

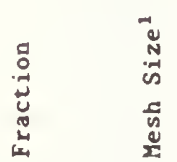

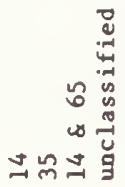

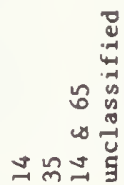

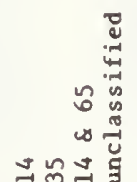

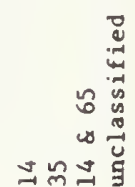

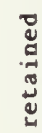

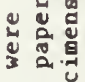

我嵌苛

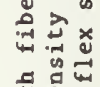

过。

능

몽유

命

둥

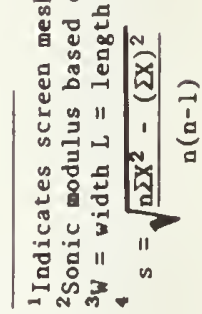




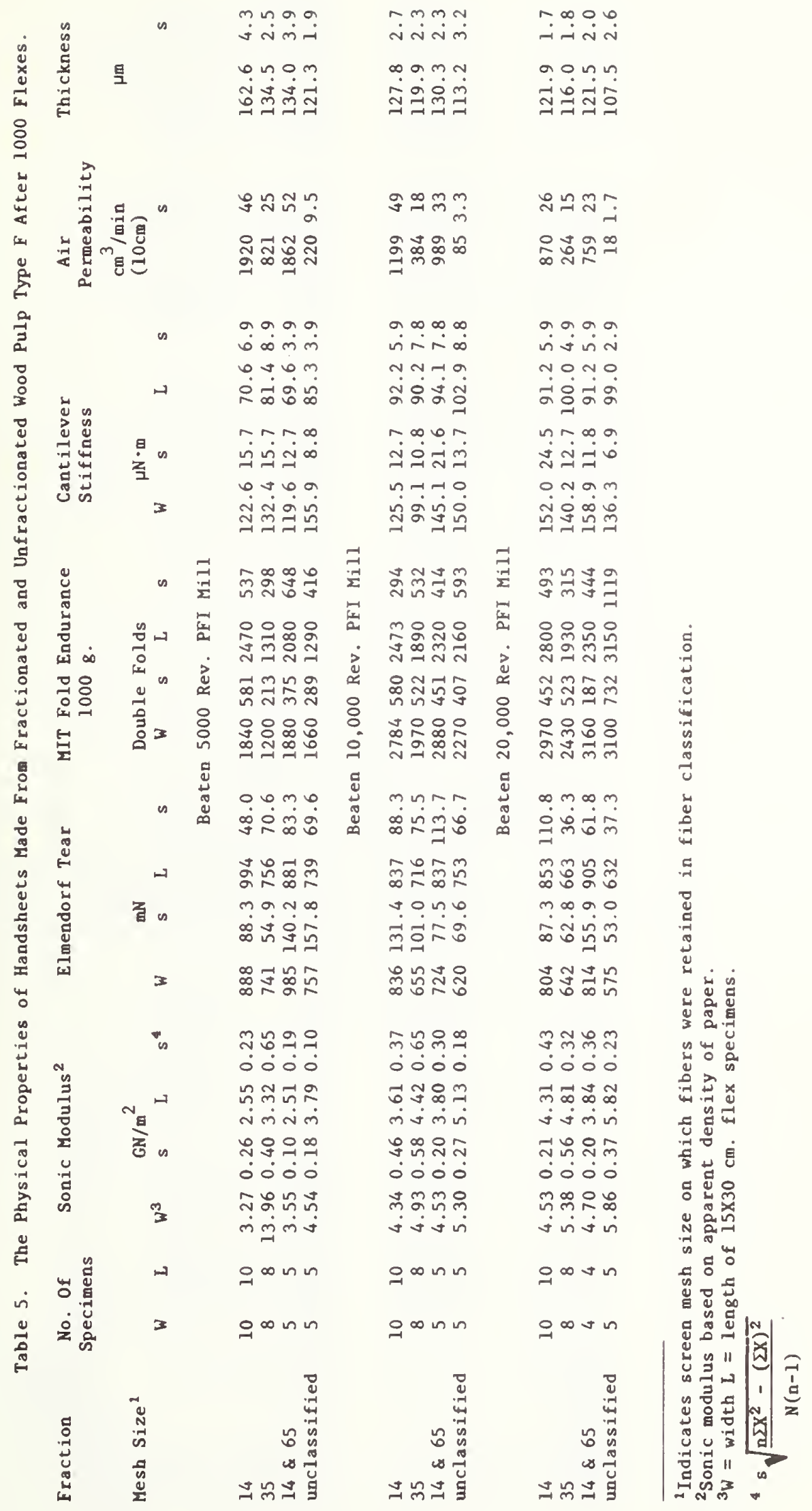




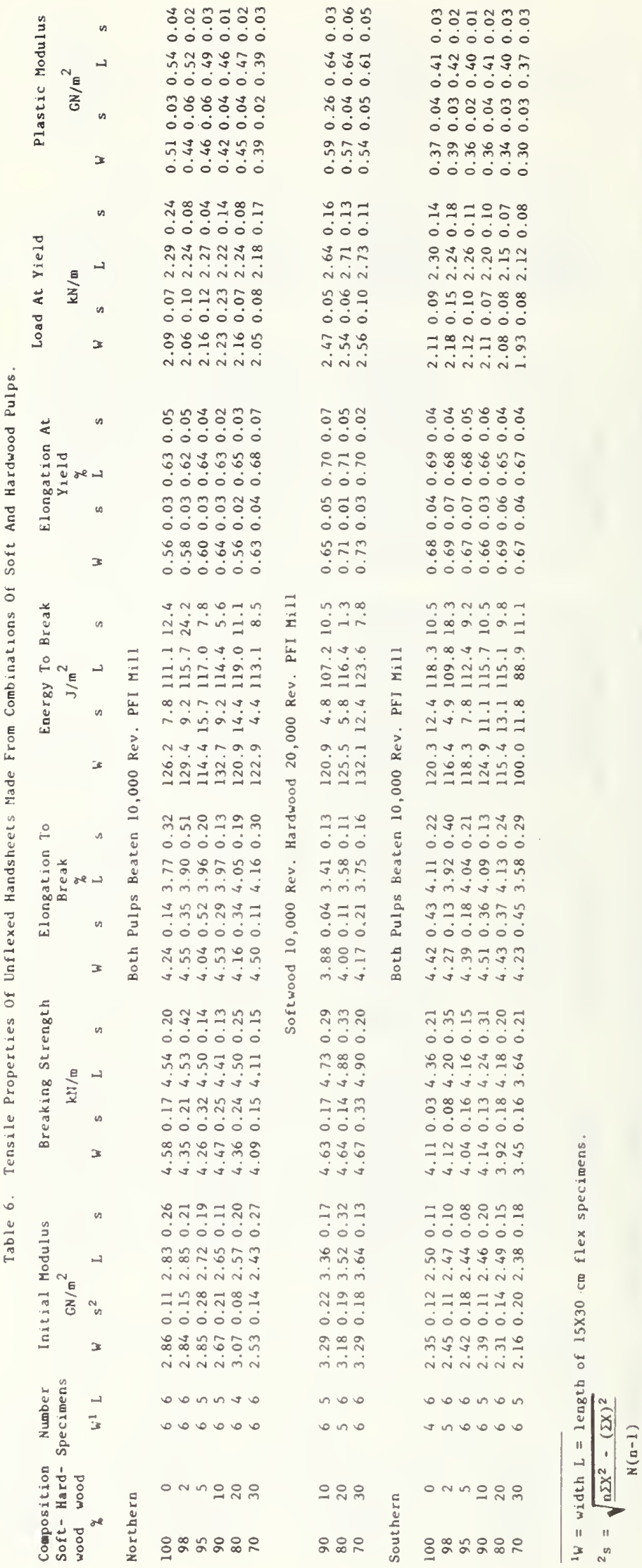




\begin{tabular}{|c|c|c|c|c|}
\hline & & 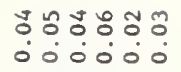 & $\begin{array}{l}0: 0 \\
0: 0 \\
000\end{array}$ & ํํㅇํㅗㅇํํㅇํㅇ \\
\hline & & 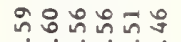 & 옹 & \\
\hline $\mathrm{N}^{\text {百 }}$ & & $00^{\circ} 00^{\circ}$ & 0. & \\
\hline 중 & $\infty$ & . & (20 & 00 \\
\hline & 3 & 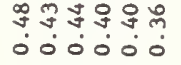 & 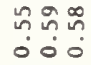 & 07 \\
\hline
\end{tabular}

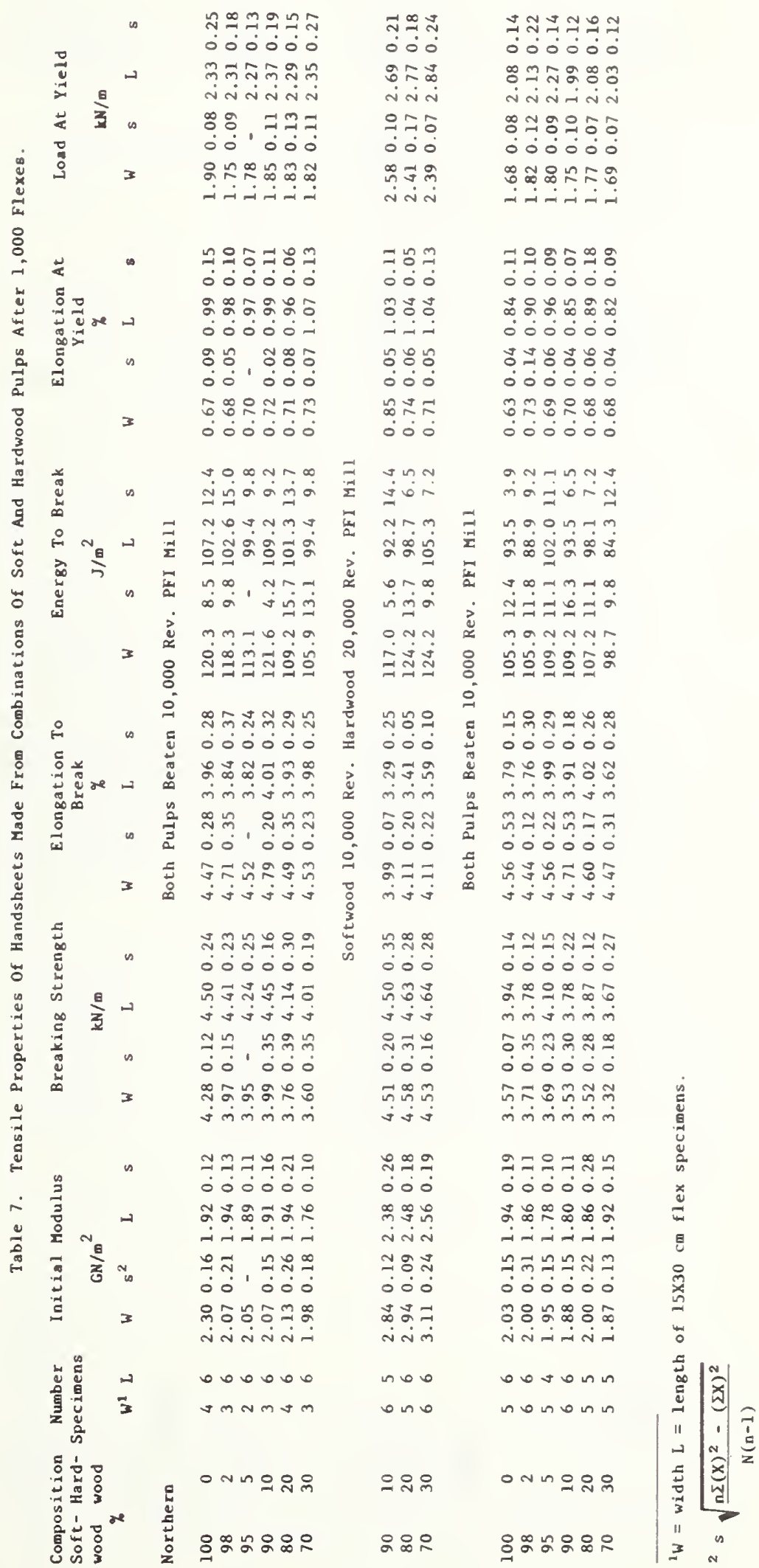




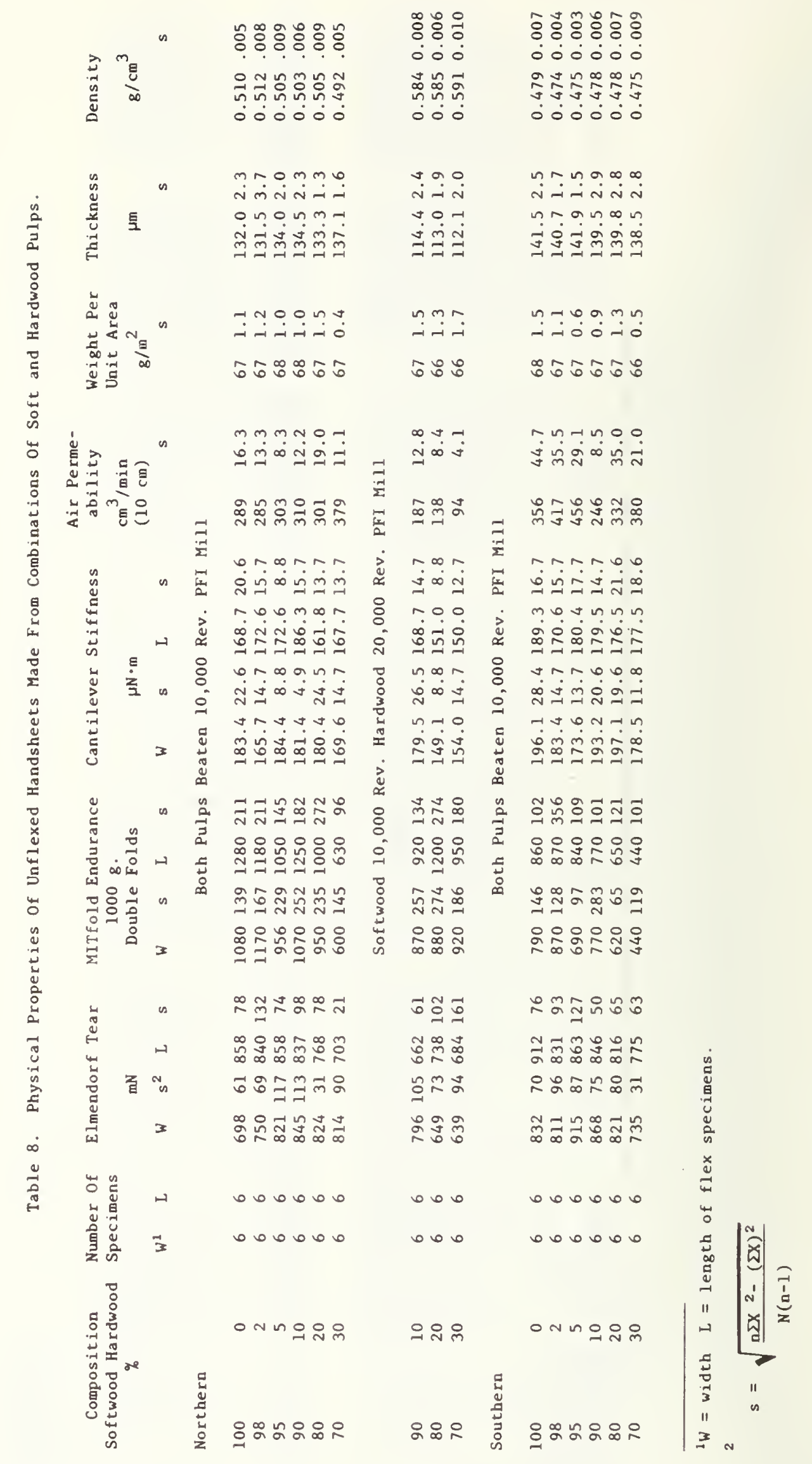


$\dot{\sigma} \underset{\sim}{\sim} \dot{\sim} \dot{\sim} \dot{\sim}$

$N \sim m$

$m \sim N m$ m

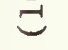

가욝

$n \pi n$

ก้ก กิก

$\stackrel{E}{E}$

¿

$\stackrel{0}{\mathfrak{N} \leftrightarrows} \stackrel{0}{\circ}$

ข้อัำชูง

$\checkmark$ in $\mathcal{N} \mathrm{m}$

in a वा क $\infty$

$\dot{0} \dot{0} \dot{i} \dot{\sim}$

nn $n$ at

mก 0 a

$\dot{z}$ i $\rightrightarrows$ a

$\dot{0} \ddot{0} \dot{0} \dot{\infty} \dot{n}$

E $\infty$ atam

$\infty$ a $\div$ -

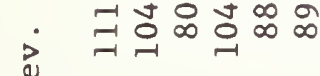

8

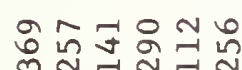

잉ㅇㅇ잉

궈ำ

드ㅁㅝㅝำ

용요용요

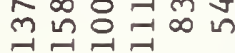

$\sum$

$\stackrel{1}{2}$

๓กㅇํ윳

드ำ

으ำ

洜

ำกำ

ำ

ขีง

오ำ

$-\infty \omega$

a a $\infty$ a $a$

0 0 ن

mmm t t

$\infty N \infty \sim \infty$

कं

$\infty \infty$

검

$\infty \sim \sim \infty \sim a$

$\infty \dot{n} \dot{m}$

- $m$ No

$\sim \rightarrow \infty$

돌

ด $\bullet \sim n \infty$

용 뭄ㄷㅁ

요

Nㅡำำ 뜸

กำ

ำ ก

ㄴํㅇㅇㅛ

잉 $\infty$

ㅇํㅇㅇํㅇ

8

요워

-

采采

N $\stackrel{0}{0} \underset{1}{\infty}$

Nํำ

กิ $\infty 2$

กำ

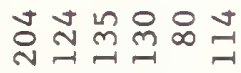

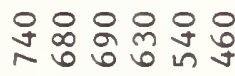

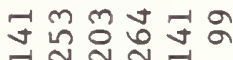

Inns

Nํㅇำ

ㄷํํำ

$\infty 0 \sim 100 \%$

$\infty$

กํํ의ำำ

$\sim \infty \infty \sim m m$

$\infty \stackrel{\sim}{\infty} \approx \mathfrak{N}$

跑

แั

$\circ 66$

๑ $\bullet \bullet \bullet$

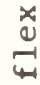

E्

(4).

$\ln ^{2}$

r.

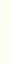

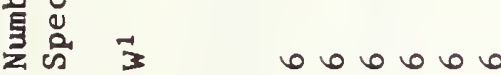

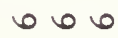

๑ $\bullet \bullet \bullet \bullet$

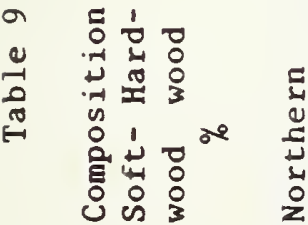

o v n 이요 을

응

- N

으옝ㅇㅇㅇ 요윰 : 

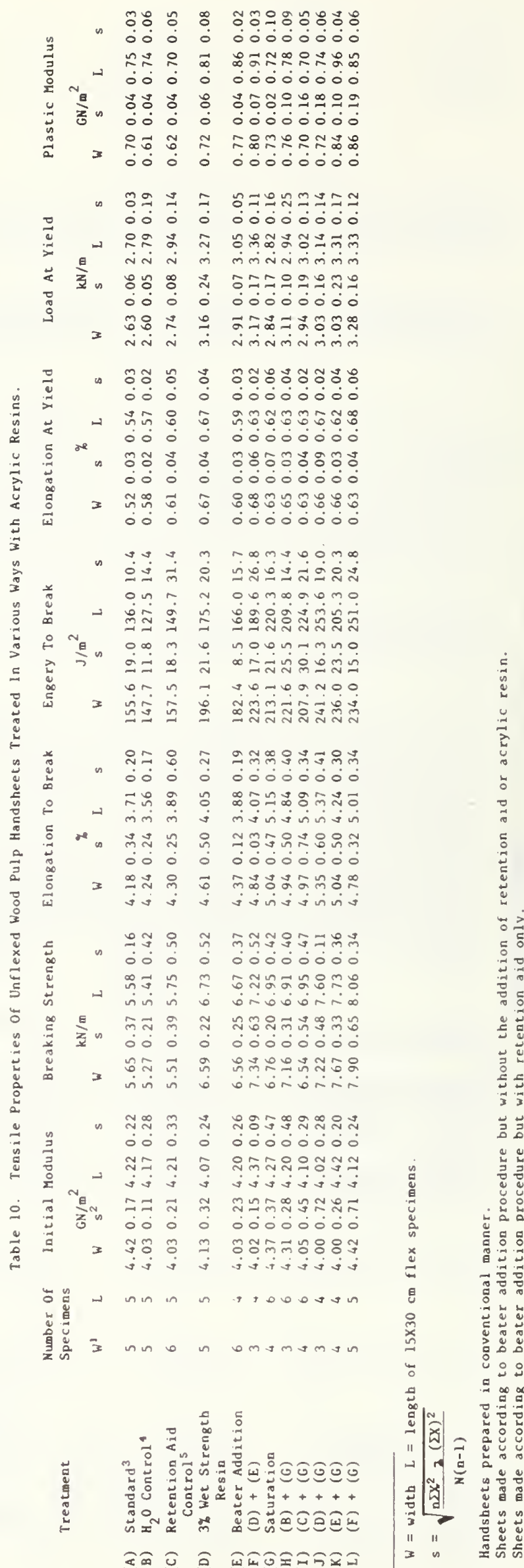


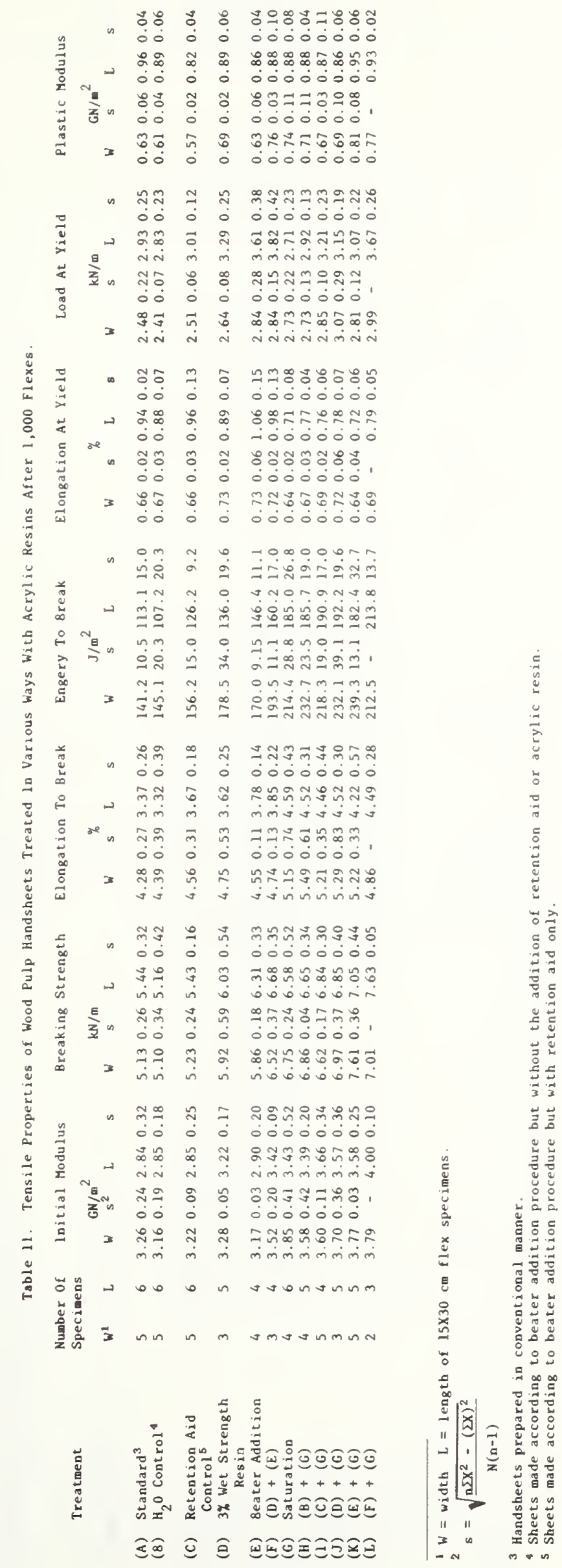




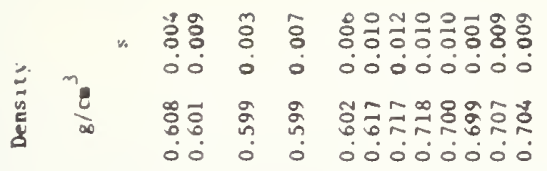

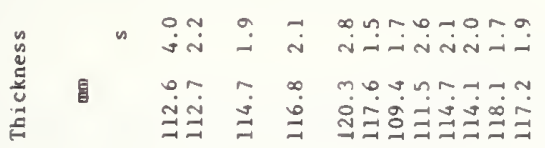

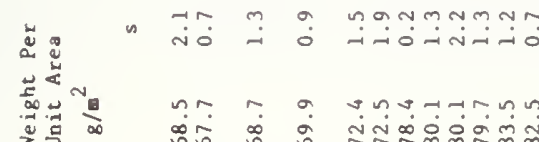

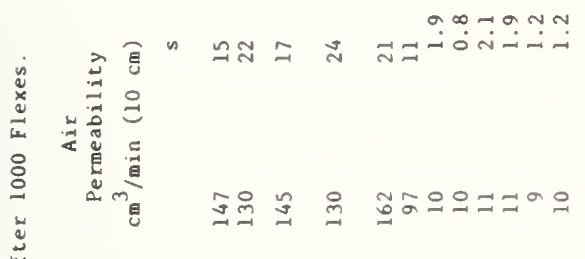
mm m a numum no

-

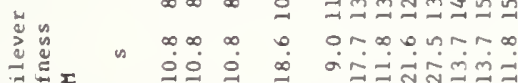

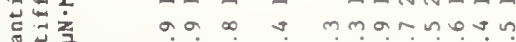

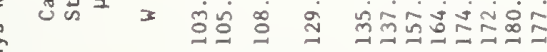

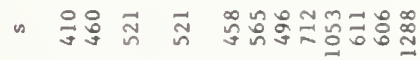

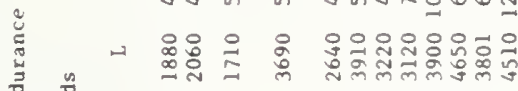

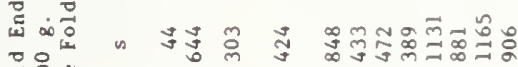

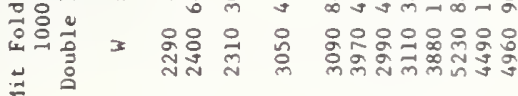
ทด ก ० munommn

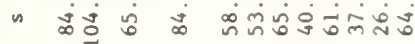
An o d onntom-a

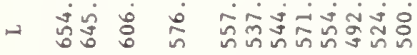

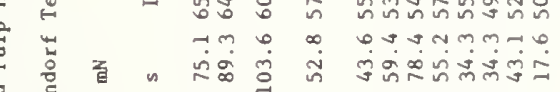

:

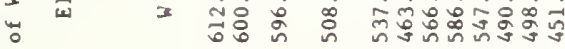

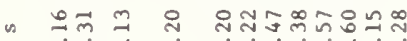

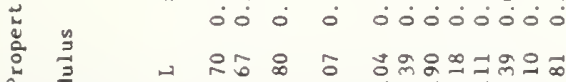

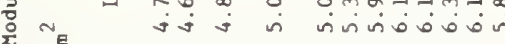

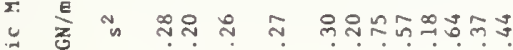

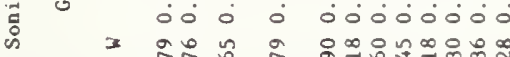

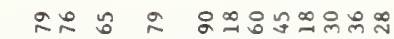

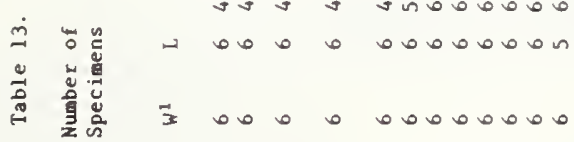

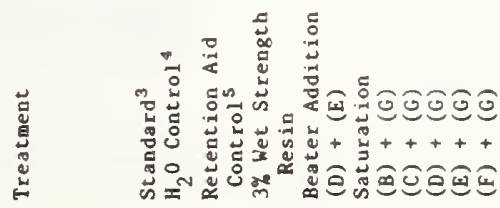

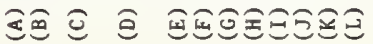


NBS.J14A IREV 7.731

\begin{tabular}{|c|c|c|}
\hline \begin{tabular}{c|c} 
U.S. DEPT. OF COMM. & 1. PUIBI.IN ATION OR RIIIORI NO. \\
BIBLIOGRAPHIC DATA & NBSIR $78-1417$ \\
SHEET & NBSI
\end{tabular} & $\begin{array}{l}\text { 2. Ciov't Accessi.nr } \\
\text { No. }\end{array}$ & 3. Recipicent's Accescion Ne. \\
\hline \multirow{2}{*}{\multicolumn{2}{|c|}{$\begin{array}{l}\text { 4. TITIE ANI SUIBTIII: } \\
\text { An Evaluation of Wood Pulp Paper Durability }\end{array}$}} & $\begin{array}{l}\text { 5. Publication } 1 \text { )atc } \\
\text { February 15, } 1978\end{array}$ \\
\hline & & 6. Performing Organization Codc. \\
\hline $\begin{array}{l}\text { 7. A(:TIIOR(S) } \\
\text { E. L. Graminski and E. E. Toth }\end{array}$ & & 8. Performing Organ. Report No. \\
\hline \multirow{2}{*}{\multicolumn{2}{|c|}{$\begin{array}{l}\text { 9. PERFORMING ORGANIYATION NAME: AND ADIORESS } \\
\qquad \begin{array}{l}\text { NATIONAL BUREAU OF STANDARDS } \\
\text { OEPARTMENT OF COMMERCE } \\
\text { WASHINGTON, D.C. } 20234\end{array}\end{array}$}} & $\begin{array}{l}\text { 10. Project/Task/Work Unit No. } \\
3110443\end{array}$ \\
\hline & & 11. Contract/Grant No. \\
\hline \multirow{2}{*}{\multicolumn{2}{|c|}{$\begin{array}{l}\text { 12. Sponsoring Organization Namc and Complete Address (Street, City, State, ZIP) } \\
\text { Bureau of Engraving and Printing } \\
\text { Washington, D. C. }\end{array}$}} & $\begin{array}{l}\text { 13. Type of Report \& Pcriod } \\
\text { Covered } \\
10 / 1 / 76-9 / 30 / 77\end{array}$ \\
\hline & & 14. Sponsoring Agcency Code \\
\hline
\end{tabular}

15. FUPPI.1:MI:NTARY NOTES

16. ABSTRAC T (A 200-word or less factual summary of most significant information. If document includes a signıficant bibliography or literature survey, mention it here.)

Currency has been printed customarily on high grade paper owing to its superior durability. During the past several years the cost of raw material for rag pulps has risen tremendously and the thought of using high quality wood pulp papers as a means of lowering the cost of currency manufacture has been advanced. While considerable work has been done on rag currency paper to resolve the origin of its superlor durability and to further increase its already excellent durability essentially little if any information has been developed for wood pulp paper durability. This report describes the results of experiments performed with wood pulp paper which had previously been performed on rag currency paper and probable reasons for observed differences were postulated.

17. KI:Y WORI)S (six to twelve entries; alphabefical order; capitalize only the first letter of the first key word unless a proper name; separated by semicolons)

Acrylic latexes; currency paper; fiber morphology, fiber network structure; paper durability; pulp mechanical treatment; rag pulps; wood pulps

18. AVAII.ABMIITY Unlimited

[x. For Official Distribution. Do Not Release to NTIS

Order lirom Sup. of Doc., U.S. Government Printing Office Washington, I).C. 20.102, SD) Cat. No. C.13

\begin{tabular}{|l} 
19. SIECURITY CI.ASS \\
(THIS REPURT) \\
UNCI. ASSIFIED \\
\hline $\begin{array}{l}\text { 20. SF( URITY (.LASS } \\
\text { (THIS PAGE) }\end{array}$ \\
UNCI.ASSIIIEI)
\end{tabular}
21. NO. OF PAGES 